\title{
Liderlik kavramının tarihçesi ve Türkiye'de ilaç endüstrisinde liderliğin önemi
}

Bilge SÖZEN ŞAHNE, Sevgi ŞAR

\section{ÖZET}

Dünyada hızla yaşanan gelişmeler, herkesi etkilediği gibi, hangi alanda faaliyet gösterirlerse göstersin, bütün örgütleri de yakından ilgilendirmektedir. Söz konusu gelişmelere ve değişimlere, örgütte görev alan herkesin uyum sağlayabilmesi için örgüt içi iletişimin sağlanması gerekmektedir.

Sağlık alanında faaliyet gösteren örgütlerde, rekabet üstünlüğü sağlamanın da önemli bir faktörü olan değişime ayak uydurma zorunluluğu daha da büyük bir öneme sahiptir. Bu aşamada da örgütte görev yapan liderlere büyük görevler düşmektedir. Bu çalışmada, liderlik kavramının tarihçesinden bahsedilerek ilaç endüstrisinde faaliyet gösteren örgütlerde liderliğin önemi vurgulanmaktadır

Anahtar kelimeler: Liderlik, İlaç Endüstrisi
Bilge Sözen Şahne

Hacettepe Üniversitesi Eczacılık Fakültesi, Eczacılık Işsletmeciliği

Anabilim Dall, Ankara, Türkiye

Sevgi Şar

Ankara Üniversitesi Eczacılık Fakültesi, Eczacılık Işsletmeciliği Anabilim Dalı, Ankara, Türkiye

\section{Sorumlu Yazar:}

Bilge SÖZEN ŞAHNE

Hacettepe Üniversitesi Eczacılık Fakültesi, Eczacılık İşletmeciliği

Anabilim Dalı, Ankara, Türkiye

E-mail: bilgesozen@yahoo.com

\section{GíRiş}

Büyük bir hızla değişen dünyada, insanlar için ürün ve hizmet üretimi gibi önemli roller üstlenen işletmelerin, bu değişime ayak uydurması kaçınılmaz bir durum olmaktadır. Organizasyonların başta yapılanmalarında olmak üzere pek çok alanda değişikliğe gitmesinin sebepleri arasında küreselleşme, insan hakları dolayısıyla çalışan hakları konusunda farkındalığın yaygınlaşması, iletişim teknolojilerindeki gelişmeler, insanların beklenti ve taleplerindeki değişiklikler gibi çeşitli durumlar yer almaktadir.

Organizasyonların yapılanmalarındaki yenilikler, yönetim anlayışında da değişikliklerin olmasını gündeme getirmiştir. Kendi içerisinde uzmanlık alanları bulunan bir çalışma alanı haline gelen yeni yönetim düşüncesinin şekillenmesinde, yukarıda belirtilen küreselleşme, insan hakları, iletişim teknolojileri gibi kavramların yanı sıra uluslararası rekabet de büyük rol oynamıştır. Organizasyonların güncel uygulamalardaki yaklaşımları

\footnotetext{
* Bu çalışma, Bilge Sözen Şahne'nin “Türkiye'de Faaliyet Gösteren İlaç Firmalarının Yöneticilerinin Liderlik Yaklaşımları” başlıklı yayımlanmamış doktora tezinden türetilmiştir.
} 
sonucunda yönetimde öne çıkan temel kavramlardan birisi de liderlik olmuştur (1). Değişen sosyal ve ekonomik koşullar nedeniyle, organizasyonlar arasındaki bu rekabette üstünlüğün sağlanabilmesi için belirlenen hedeflere liderlerin yönetiminde ulaşılabilineceği belirtilmektedir (2-4).

Liderliğin, organizasyonlarda pek çok unsurun yanı sıra örgüt kültürü ile de ilişkili olduğu bilinmektedir. Özellikle bazı çalışmalar, liderlik tarzının çalışan performansını, kişiler arasındaki etkileşimi ve örgüt kültürünü etkilediğine yer vermektedir $(5,6)$. Birbirinin tamamlayıcısı olarak değerlendirilen bu iki kavram, organizayonlar açısından da büyük önem taşımaktadır (6). Örgüt kültürü, liderlik sürecinin bir sonucu olarak değerlendirilmekte ve liderlik davranışından çokça etkilenmektedir, ancak liderliğin örgüt kültürünü değiştirmesi değil iyi yönde katkıda bulunması istenmektedir $(6,7)$. Liderliğin örgüt kültürü ile birlikte iş doyumu ve örgütsel bağl1lı̆̆g da etkileyen bir faktör olduğu vurgulanmaktadır (8).

Liderlik, gerek kavramsal gerek tarihsel açıdan oldukça eski bir olgudur. Anglosakson kökenli bir sözcük olan ve yol anlamına gelen lead kelimesinin, leader sözcügünün kökenini oluşturduğu kabul edilmektedir (9). Türkçe'de önder kelimesinin karşılığ 1 olan lider ve liderliğin tarihi, insanların topluluk halinde yaşamaya başlamasına kadar dayanmaktadır (10). Ayrıca bu konu ile ilgili araştırmalar her ne kadar Sanayi Devrimi'nden sonra artsa da, liderlik, ilk çağlardan beri toplumdaki her bireyin ilgisini çeken ve üzerinde çeşitli araştırmaların yapıldı ̆̆ bir konu olmuştur $(11,12)$.

Bu bağlamda, organizasyonlarda yönetici pozisyonunda yer alan kişilerin liderlik vasıfları taşımasının gerekliliği, günümüzde tartışmasız olarak kabul edilmektedir. Özellikle sağlık alanında faaliyet gösteren işletmelerde liderlik ayrıca büyük önem arz etmektedir. Bu çalışma kapsamında liderlik kavramının tarih içerisindeki yerinden başlayarak, sağlik sektörü ve ilaç endüstrisindeki yeri aktarılmaya çalışılmaktadır.

\section{LIDEERLIKK KAVRAMININ TARIIHÇESİ}

Antik dönemlerde daha çok geniş kitleler üzerinde büyük etkisi olan kişilerle birlikte anılan liderlik ve içerdiği kavramlar, zaman zaman çeşitli mitolojik tanrılarla özdeşleştirilmiştir. Liderlerin iletişim erdeminin Hermes, strateji geliştirebilme özelliğinin Athena ve gücünün Zeus'la ilişkilendirildiği görülmektedir (13). Mısır'da ise benzer şekilde liderlik anlayışı tanrı-kral anlayışı ile paralellik göstermektedir. Antik Çin'de de liderlik kavramına rastlandığ 1 bilinmektedir (14).
Çeşitli kaynaklarda, tarihte yer alan pek çok ünlü bilim insanının çeşitli şekillerde liderlikten bahsettiğine dair bilgiler bulunmaktadır. Ayrıca liderliğin temel ilkelerinden olduğu kabul edilen "Her şeyden önce zarar verme" ilkesinin kökeninin, Hipokrat'1n "Primum non nocere" sinden geldiği düşünülmektedir (15).

Homeros'un İlyada ve Odysseia isimli eserlerinde liderlik kavramına yönelik çeşitli tanımlamaların olduğu belirtilmektedir. Liderliğin adlandırılmasının ise ilk kez Platon tarafindan "Çevreyi dolaşarak yönetmek" şeklinde yapıldığ 1 varsayılmaktadır (16). Ksenophon'un yazdığ 1 Cyropaedia ise liderlik üzerine yazılmış ilk sistemli kitap olarak kabul edilmektedir. Ayrıca yazarın diğer önemli bir eseri olan Anabasis (Onbinlerin Dönüşü)'de de etkin ve etik liderlikle ilgili önemli bilgiler yer almaktadır (15).

Julius Ceasar'ın M.Ö. 58-52 y1llarında, Roma Senatosu önünde yaptığı konuşmalarında da, liderlerin taşıması gereken özelliklerden bahsettiği belirtilmektedir (17). Ayrıca lider kelimesinin ilk kez 1300'lü yıllarda ortaya çıktığı düşünülmektedir. Bunun yanı sıra 19. yüzyılın başlarında, İngiliz Parlamentosu'yla ilgili, liderlik kavramının geçtiği yazılara da rastlanılmıştır (18).

İlk ve Orta Çağlarda daha çok güç ve iktidar kullanımının bir göstergesi olarak algılanan liderlik kavramına, demokratik yapıların yaygınlaşması ile birlikte 20. yüzyılda daha sık karşıllaşmaya başlanılmıştır (19).

Liderlikle ilgili çalışmalar incelendiğinde tarihte pek çok iyi ve kötü lider örneği görülmektedir. Bu çalışmalarda; Mustafa Kemal Atatürk, Mahatma Gandhi, Büyük İskender, Adolf Hitler ve Martin Luther King gibi tarihteki önemli isimlere sıklıkla yer verilmektedir (17, 20-24).

$\mathrm{Bu}$ isimlerden Hitler ırkçı değerleri ve ahlaki açıdan olumsuz yönleri ile kötü; Gandhi ise şiddete karşı direnişi ile iyi örnekler arasında yer almaktadır $(20,23)$.

Mustafa Kemal Atatürk'ün ise liderlikle ilgili çalışmalarda ayrı bir yeri vardır. Tarihteki en önemli karizmatik liderlerden biri olan Atatürk; askeri, sivil ve politik alanlarda güçlü bir lider olma farklılığına sahip bir kişi olup, Türk Milleti'nin kurtarıcıs1 olarak tarihte yerini almıştır $(22,24)$. Atatürk, başarılı bir yönetimle, büyük bir dönüşümü gerçekleştirmiş ve bir milleti arkasına alarak dünyada önemli izler bırakmıştır. Bu durum O'nun bütün liderlik özelliklerini bir arada taşıdığının göstergesi olarak değerlendirilmektedir (21). Ayrıca aklı, vizyonu ve karakteriyle de örnek bir lider olduğu tartışmasız olarak kabul edilmektedir (24).

Toplumun lider algısının, tarihte devlet yönetimi veya dinle alakalı konular üzerine yoğunlaştığ 1 , günümüzde ise liderlik kavramının çoğunlukla işletmeleri ilgilendiren konularda 
gündeme geldiği görülmektedir (13). Bütün işletmeler de olduğu gibi sağlık alanında faaliyet gösteren organizasyonlarda da liderlik kavramı büyük önem arz etmektedir.

\section{SAĞLIK SEKTÖRÜNDE LIDDERLIKK}

Sağlik sektöründeki rekabet, kişilerin temel haklarından olan sağlıklı yaşam hakk1 konusunda toplumun bilinçlenmesi ve taleplerinin bu yönde gelişmesi sonucunda, artı̧̧ göstermiştir. Bu sektörünün en önemli bileşenlerinden olan ilaç endüstrisi de bu rekabetin oldukça yüksek olduğu bir alanı teşkil etmektedir. İlaç endüstrisinde faaliyet gösteren şirketler, rekabet üstünlüğünü sağlamak ve talebe cevap verebilmek için kendilerini ileriye taşıyacak, liderlik yapabilecek yöneticilere ihtiyaç duymaktadır (25). Bunun yanı sıra kişileri yönlendirebilme yeteneği olan liderlerin, öncelikle kendilerini izleyenlere örnek olabilmeleri, yaptıkları işlerdeki doğruluğu ve dürüstlüğü gösterebilmeleri için etik liderlik özelliklerine de sahip olmaları büyük önem taşımaktadır. Özellikle sağlık sektörü açısından düşünüldüğünde, liderlik özelliği olan yöneticilerin etik davranışlar sergilemeleri önem arz etmektedir.

Sergiledikleri yönetim ve liderlik özellikleri sonucundaki başarıları büyük kazançlar sağladığı kadar, hataları büyük kayıplara da neden olabilen liderlerin, doğru davranışları sergileyebilmeleri açısından, işletmelerin yapabileceği girişimler de bulunmaktadır. Özellikle sağlık alanında çalışan kişilerin kendilerini geliştirebilmesi için eğitim faaliyetlerinin yoğun olarak yürütüldüğ ü bilinmektedir (26-29).

Sağlık hizmetlerinde görev yapan liderlerin, sözleri ile değil, davranışları ile vizyonlarını göstermeleri gerekmektedir. Eğer bu liderler değişime ayak uyduramazlarsa çalışanlarının ayak uydurması beklenemez (30). Vazgeçilmesi mümkün olmayan bir alan olan sağlık sektöründe görev yapan yöneticilerin kendilerini yetenekleri konusunda geliştirmeleri ve bu liderlerin diğer sektörlerdeki liderlere göre daha duyarlı ve özenli olmaları gerekmektedir (31). Yaşam kalitesinin artmasıyla birlikte sağlıkla ilgili hizmet veren kuruluşların arasındaki rekabet de artmıştır. $\mathrm{Bu}$ nedenle kurumların, birbirlerine rekabet üstünlüğü sağlayabilmesi için güçlü liderlere ihtiyaçları bulunmaktadır (25).

Sağlık alanında faaliyet gösteren kurum ve kuruluşlarda liderlik ile ilgili gerek uluslararası gerek ulusal pek çok çalışma bulunmaktadır. Bu çalışmaların büyük bir kısmında vurgulanan ortak nokta ise, sağlık alanında liderlik söz konusu olduğunda sahip olunan değerlerin daha çok ön plana çıkmasıdır.
Ülkemizde de liderlik kavramı kapsamında sağlık sektöründe çeşitli çalışmaların yapıldığı bilinmektedir. Bunlardan bazıları şu şekilde sıralanmaktadır:

- Yiğit' in hemşirelerin liderlik davranışları ile ilgili çalışması sonucunda klinik sorumlusu hemşirelerin liderlik davranışlarına sahip oldukları belirlenmiştir (32).

- 2005 yılında hastanelerde liderlik davranışının iş doyumuna yönelik etkisini belirlemek amacıyla yapılan bir çalışmada da katılımlı, başarı yönelimli ve destekleyici liderlik tarzlarının personel iş doyumu üzerinde olumlu etkisinin olduğu ortaya konulmuştur (33).

- Ankara'daki çeşitli hastanelerde yürütülen bir çalışmada ise servis sorumlusu hemşirelerin iş ve insana yönelik liderlik yönelimleri çeşitli değişkenler dikkate alınarak incelenmiş ve yönetici hemşirelerin uygulanan ölçek kapsamında insana yönelik liderliklerini geliştirebilmeleri için çeşitli öneriler sunulmuştur (34).

- Afyonkarahisar'daki hastanelerde liderlik ve örgütsel bağl1lık ilişkisini inceleyen bir çalışma sonucunda liderliğin, çalışanların örgütsel bağlılığını olumlu yönde etkilediği bilgisine ulaşılmıştır (35).

- Hastane yöneticilerinin, vizyoner liderlik özelliklerinin belirlenmesi amacıyla Ateş ve arkadaşları tarafından yapılan bir çalışmada, Kocaeli'ndeki bazı kamu hastanelerinin yöneticilerine anket uygulanarak bu kişilerin vizyoner liderlik algıları belirlenmiştir (36).

- Özkurt ve arkadaşları tarafından, Eskişehir'de yapılan benzer bir çalışmada; bu ilde görev yapan sağlık yöneticilerine yönelik anket uygulanmasında, bu kişilerin liderlik davranışlarının yanı sıra uyumları, ekip çalışmasına yatkınlıkları gibi çeşitli konulardaki görüşlerine de yer verilmiştir (37).

- Erturgut ve Erturgut tarafindan hastane yöneticileri ile yapılan bir çalışma sonucunda, sağlık kurumlarında yöneticilerin dönüştürücü liderlik özelliklerinin öne çıktığı belirlenmiştir (21).

- Aslan ve Özata tarafindan yapılan bir çalışmada da sağlık çalışanlarında yaygın olarak görülen hizmetkar liderlik tarzının incelenmesi için hazırlanan gerekli ölçeklerin geçerlik ve güvenirlik araştırması yapılmıştır (38).

- Yeşilkayalı ve Kılıç tarafindan 2012 yılında yapılan bir çalışmada ise çalışmanın uygulandığı hastane yöneticilerinin zayıf yönetici olarak saptanması, kamudaki liderlik uygulamaların gerilemesinin bir göstergesi olarak değerlendirilmiştir (39).

- Yine hemşirelerin liderlik özelliklerinin incelendiği, Göksel ve Aydıntan tarafından yapılan bir çalışma sonucunda da lider-üye etkileşiminin örgütsel bağlılığı olumlu yönde etkilediği sonucuna ulaşılmıştır (40). 
- İlaç mümessilleri ile yapılan bir çalışmada ise etik liderlik ve etik iklimin iş performansına etkisi üzerinde durulmuştur (41).

- Liderlik konusunun sıkça ele alındığı hemşirelik alanındaki başka bir çalışmada ise hemşirelik öğrencilerinin, liderlikle ilgili özelliklerin kazandırılmasına yönelik bir eğitimin kendilerine verilmediğini düşündükleri belirlenmiştir (42).

$\mathrm{Bu}$ çalışmalardan da anlaşıldı $\breve{g}_{1}$ gibi Türkiye'deki çalışmaların çoğunluğu hastane yönetimi ve hemşirelik alanlarında yapılmış çalışmalar olup, ilaç sektöründe liderlik ile ilgili sadece bir adet çalışmaya rastlanılmıştır.

\section{TÜRKIYE'DE İLAÇ ENDÜSTRISININE LIDERLIIĞIN ÖNEMİ}

Küreselleşme ile yaygınlaşan gelişmeler ve değişiklikler, pek çok alanda olduğu gibi sağlık alanında da etkisini göstermiştir (43). Geçtiğimiz yüzyılda sağlık alanında yaşanan önemli gelişmeler içerisinde, ilaç endüstrisinin insan sağlığının ve yaşam kalitesinin iyileştirilmesine önemli katkılarının olduğu bilinmektedir (44). Sağlık sektöründe, özellikle ilaç kullanımı ile ilgili konularda önde gelen sektörlerden ilaç endüstrisinin bu konuda geliştirici, üretici, pazarlayıcı ve satıcı gibi çeşitli rolleri bulunmaktadır (45).

Türk İlaç Endüstrisi’nin tarihine bakıldığında, temellerinin Osmanlı Devleti Dönemi'nde atıldığı görülmektedir. Bu bağlamda, 1800'lü yıllarda hazır ilaç olarak bulunabilen ilk ilaçların Tiryak ve Melisa Ruhu olduğu bilinmektedir. Ayrıca, yine bu dönemde İngiliz Eczanesi'nde hazırlanan ilaçların ve 1880 yılında Ecz. Halil Hamdi Bey'in eczanesinde yaptığı üretimlerin, ülkemizde üretilen ilk ilaçlar olduğu belirtilmektedir (46, 47). 1895 yılında Ecz. Ethem Pertev Bey'in ürettiği Pertev Şurubu'nun ilk Türk müstahzarı, 1900'lü yıllarda kurulan Osmanlı Komprime Laboratuvarı'nın ise ilk üretim tesisi olduğu, bu konu ile ilgili pek çok kaynakta yer almaktadır. Artan ihtiyacın karşılanabilmesi için Cumhuriyet Dönemi'nde sağlanan olanaklarla günümüzdeki şekliyle ilaç endüstrisinin şekillendiği; ilerleyen teknik imkanlarla birlikte, ilaç üretiminde laboratuvarlardan fabrikalara geçişin yapılarak büyük fabrikalarda üretimin 1950'li yılların başında başladığı bilinmektedir (46-48).

Ülkemizde, günümüze kadar önemli aşamalar kaydederek büyük bir sektör haline gelen ilaç sektörü; "Beşeri ve veteriner hekimlikte tedavi edici, koruyucu ve tanı amaçl olarak kullanilan sentetik, bitkisel, hayvansal ve biyolojik kaynaklı kimyasal maddeleri farmasötik teknolojiye uygun olarak üreterek sağllk hizmetlerine sunulmasını sağlayan bir sanayi dalı" olarak tanımlamaktadır $(49,50)$. İlaç sanayinin faaliyet gösterdiği alt sektörler ise beşeri ilaç üretimi, veteriner ilaç üretimi, ilaç hammaddeleri üretimi ile diagnostik ve diğer farmasötik ürünler üretimidir (50).

Sektörün ürettiği ürünler ise provitamin ve vitaminler, hormonlar ve türevleri, glikozitler, bitkisel alkaloidler, antibiyotikler, tedavide kullanılan organlar, kan, serum ve aşılar, ilaçlar, gaz bezleri ve steril malzemeler olarak sinıflandırılmaktadır (51).

Her ne kadar ilaç tüketimi en çok ABD, AB ve Japonya gibi ülkelerde olsa da, ülkemizin de bu pazarda önemli bir yeri bulunmaktadır. İlaç sektörü, ürettiği ürünlerin ikame edilememesi, yüksek eğitim almış kişilerin istihdamına imkan vermesi, sahip olduğu Ar-Ge potansiyeli nedeni ile büyük yatırımlara olanak sağlaması, ülkeler için stratejik öneme sahip olan tıp ve eczacılık alanlarında sağladığ 1 katkılar nedeni ile önemli bir sektör olarak kabul edilmektedir (49). Türkiye'de faaliyet gösteren ve bir kısmı yabancı sermayeli olan firmaların yaklaşık altıda birinin üretim tesisi bulunmaktadır. Sektörde yaklaşık olarak 25000 kişinin istihdam edildiği belirtilmektedir $(50,51)$.

Türkiye'de ilaç sektörünün daha iyi koşullara gelebilmesi ve dünya çapındaki rekabet gücünün arttırılması için hazırlanan Türkiye İlaç Sektörü Stratejisi ile ilgili çalışmalar, T.C. Bilim, Sanayi ve Teknoloji Bakanlığ 1 Sanayi Genel Müdürlüğü önderliğinde yürütülmektedir (50).

Türkiye'de ilaç sektörü her ne kadar kimya sektörünün bir alt dalı olarak değerlendirilse de, sağlıkta istenilen gelişmelerin yaşanabilmesi için, bu alandaki gelişmelerin sağlık alanını ön plana alarak yapılması gerekmektedir. Sağlık alanında iyileşmenin sağlanabilmesi için de sürdürülebilir bir sisteme ihtiyaç bulunmakta ve bu sistem içerisinde ilaç sektörü önemli bir yere sahip olmaktadır (52).

İlaç firmalarının organizasyon yapıları da temelde benzer nitelikler taşısa da birbirlerinden farkl1lıklar göstermektedir. İlaç endüstrisi gibi sektörlerde liderlik kavramı, genellikle teknik liderlikten grup liderliğine ilerleme şeklinde olmaktadır (53). Aynı zamanda ilaç sektörü, bütün sektörler arasında en fazla yönetici değişiminin yaşandı sektörlerden biri olmasina rağmen ilaç endüstrisinde görev yapan pek çok yöneticinin, araştırmacıları nasıl motive etmesi gerektiğini bilmediği göze çarpmaktadır (54-56). Bu nedenle günümüzde ilaç firmalarının lider geliştirmeye yatırım yapmaları daha büyük önem taşımaktadır (56).

İlaç endüstrisi gibi, profesyonelliğin ve bilimselliğin bir arada olduğu işletmelerde, yönetici pozisyonlarında görev yapan kişilerin takım-birey, lider-araştırmacı, bütünlükheterojenlik gibi çeşitli ikiliklerin üstesinden gelmesi beklenmektedir (57). 
Dünya çapındaki finansal krizle birlikte ilaç sektöründe de çeşitli sıkıntılar yaşanmaktadır. Bundan 5-10 yıl sonra ilaç endüstrisinin ne durumda olacağına ilişkin sorular gündeme gelmektedir (44). Sektördeki rekabetin fazlalığı, yeni ürün geliştirmede yaşanan problemler, çeşitli hükümet politikaları, müşteri beklentileri, pazarlama esnasında yaşanan sıkıntılar, bütçe zorlamaları ve zaman kısıtlılığ gibi zorluklarla baş edebilecek liderlerin ilaç firmalarının yönetim kademelerinde yer alması gerekmektedir $(45,56$, $58,59)$.

Hükümetler, toplum, pazarda faaliyet gösteren ilaç firmaları ve sigorta şirketleri gibi çeşitli etkenlerin sağlık sistemleri üzerindeki etkisi bilinmektedir $(60,61)$. Bu nedenle insan sağlığı üzerine doğrudan etkisi bulunan ilaç gibi önemli bir ürünün meydana gelişinden kullanımına kadar görev alan yöneticilerin görevlerinin öneminin farkında olmaları büyük önem taşımaktadır $(31,62,63)$. Aksi takdirde bu kişilerin yapacakları gerek yönetsel, gerekse etik hataların bedelleri hem maddi açıdan hem de sağlık açısından çok büyük olabilmektedir $(30,31,64,65)$.

Avrupa'da 6., dünyada ise 14. olan Türkiye İlaç Pazarı, 1990'lardan beri bu alanda faaliyet gösteren uluslararas1 firmalar için vazgeçilmez olmuştur. Ancak tüm dünyada olduğu gibi Türkiye'de de ilaç endüstrisinin içerisinde bulunduğu zor durum, önümüzdeki yıllarda bu sektörün yaşayabileceği sorunlarla baş edebilecek liderlere olan gereksinimin artmasına neden olmaktadır $(44,66)$. Türkiye'nin ilaç sektöründe istediği konuma gelebilmesi için sektörün hükümetle işbirliği içinde olmasının gerekliliği belirtilmektedir (67). Aynı zamanda bu sektörde yaşanan etik sorunlar nedeniyle ilaç endüstrisinde etik liderlik de ayrı bir önem arz etmektedir (41).

\section{SONUÇ}

İnsanların birlikte yaşamaya başlaması ile birlikte ortaya çıkan bir kavram olan liderlik, özellikle Sanayi Devrimi'nden sonra pek çok bilimsel çalışmanın yoğunlaştığı bir alan haline gelmiştir. Farklı sektörlerde liderlikle ilgili sayısız çalışma olmasına rağmen, özellikle ilaç sektöründe bu konu ile ilgili çalışma sayısının oldukça az oluşu dikkat çekicidir.

Etkili liderliğin, sektörlerin gelişmesinde önemli katkılarda bulunduğu bilinmektedir. Liderliğin işletmeler açısından olumlu etkisi ve sonradan da kazanılabilen bir beceri olduğu kabul edildiği takdirde, bütün organizasyonların yöneticilerinde liderlik özellikleri araması kaçınılmaz olacaktır. Bu nedenle özellikle sağlık sektöründe ve ilaç endüstrisinde görev yapan yöneticilerin kendilerini bu alanda geliştirmeleri gerekmektedir. Bunun için uygun eğitim programlarının seçilerek kişileri, dolayısıyla da işletmeleri daha ileriye taşıyabilecek liderlik özelliklerinin kazanılmasına yönelik uygulamaların yapılması gerekmektedir. Bu noktada, verilecek eğitimlerde aktarılması planlanan bilgilerin özenle seçilerek, uygulanıp uygulanmadığının kontrol edilmesi büyük önem taşımaktadır.

\section{The History of Leadership and The Importance of Leadership in the Turkish Pharmaceutical Industry}

\section{ABSTRACT}

Fast developments in the world influence not only everybody but also all the organizations in regardless of whatever sector they work. Interprofessional and interorganizational communication is required to be enabled for everybody working in the organization to adapt to the development and changes.

In health-related organizations, obligation to adapt to the change, a significant factor of providing competitive advantage has greater significance. In this phase, leaders working in organization have greater roles.

In this study, the history of leadership is explained and the significance of leadership in pharmaceutical industry is emphasized..

Key words: Leadership, Drug industry

\section{KAYNAKLAR}

1. Koçel T. İşletme yöneticiliği - yönetim ve organizasyon: organizasyonlarda davranış klasik, modern, çağdaş ve güncel yaklaşımlar. Arıkan Basım Yayım Dağıtım, Ankara. 2005.

2. Tengilimoğlu D. Kamu ve özel sektör örgütlerinde liderlik

davranış1 özelliklerinin belirlenmesine yönelik bir alan çalışması. Elektronik Sosyal Bilimler Dergisi 2005;4: $1-16$.

3. Kalshoven K, Den Hartog DN, De Hoogh AHB. Ethical Leader Behavior and Big Five Factors of Personality. J Bus Ethics 2011;100:349-66. 
4. Resick CJ, Hanges PJ, Dickson MW, Mitchelson JK. A crosscultural examination of the endorsement of ethical leadership. J Bus Ethics 2006;63:345-59.

5. Ogbonna E, Harris LC. Leadership style, organizational culture and performance: empirical evidence from UK companies. Int J Hum Resor Man 2000;11: 766-88.

6. Shein EH. Organizational culture and leadership.Jossey-Bass A Wiley Imprint, ABD. 2004.

7. Özmutaf NM. Liderliğin örgüt kültürü içinde değişimsel boyutta değerlendirilmesi. Süleyman Demirel Üniversitesi Sosyal Bilimler Enstitüsü Dergisi 2007;2: 83-9.

8. Şencan N, Yeğenoğlu S, Aydıntan B. Sağlık çalışanları ve eczacılar üzerine yapılan iş doyumu ve örgütsel bağlılık araştırmaları. Marmara Pharm J 2013;17: 104-12.

9. İbicioğlu H, Özmen Hİ, Taş S. Liderlik davranışı ve toplumsal norm ilişkisi: Ampirik bir çalışma. Süleyman Demirel Üniversitesi İktisadi ve İdari Bilimler Fakültesi Dergisi 2009; 14:1-23.

10. Alkın C, Ünsar S. Liderlik özellikleri ve davranışlarının belirlenmesi üzerine bir araştırma. Gazi Üniversitesi İktisadi ve İdari Bilimler Fakültesi Dergisi 2007;9: 75-94.

11. Yurtkoru ES, Ekmekci AK. Actual and ideal leadership behavior shift within the last five years. Procd Soc Behv 2011;24: 1451-9.

12. Avcı U, Topaloğlu C. Hiyerarşik kademelere göre liderlik davranışlarını algılama farklılıkları: Otel çalışanları üzerinde bir araştırma. KMU İİBF Dergisi 2009;11:1-20.

13. Hatch MJ, Kostera M, Kozminski AK. The three faces of leadership: manager, artist, priest. Org Dyn 2006;35:49-68.

14. Howell JP, Costley DL. Understanding Behaviors for Effective Leadership. Pearson, New Jersey. 2006.

15. Cohen WA. Drucker ve Liderlik. Optyimist Yayınları, İstanbul. 2010.

16. Tabak A, Yalçınkaya H, Erkuş A. Liderlik Kavramına Tarihsel Bir Bakış. İçinde: 21 Yüzyılda Rusya, AB ve Türkiye'den Yansımalar. Editör O. Kaymakçı, Türkmen Kitapevi, İstanbul. 2007.

17. Van Tassel JM, Poe-Howfield L. Leadership and management. managing electronic media: Making, marketing and moving digital content. Focal Press/Elsevier. 2010.

18. Demir C, Yılmaz MK, Çevirgen A. Liderlik yaklaşımları ve liderlik tarzlarına ilişkin bir araştırma. Alanya İşletme Fakültesi Dergisi 2010;2:129-52.

19. Tabak A, Polat M, Coşar S, Türköz T. Otantik liderlik ölçeği: Güvenirlik ve geçerlik çalışması. İş, Güç Endüstri İlişkileri ve İnsan Kaynakları Dergisi 2012;14:89-106.

20. Ketola T. Responsible Leadership: Building blocks of individual, organizational and societal behavior. Corp Soc Resp Env Ma. 2010;17:173-84.

21. Erturgut R, Erturgut P. Transformasyonel lider karizmatik mi? Vizyoner mi? Sağlık örgütlerinde bir araştırma. Elektronik Sosyal Bilimler Dergisi 2010;9:223-39.
22. Dural AB. The Leadership of Mustafa Kemal Atatürk: Turkish Independence War. ESJ 2012;8: 184-201.

23. McCall JJ. Leadership and ethics: Corporate accountability to whom, for what and by what means? J Bus Ethics 2002;38:133-9.

24. Kalca M. Tarihteki Ünlü Komutanlar-Liderler. İstanbul: Karma Kitaplar; 2012.

25. Keklik B. Sağlık hizmetlerinde benimsenen liderlik tiplerinin belirlenmesi: Özel bir hastane örneği. Afyon Kocatepe Üniversitesi İIBF Dergisi 2012;14:73-93.

26. Özler Kıral D, Şar S. Satış gücü eğitiminin Türk ilaç endüstrisindeki önemi. Ankara Üniversitesi Eczacılık Fakültesi Dergisi 2004;33:243-54.

27. Brazeau GA. Leadership and learning. Am J Pharm Educ. 2008;72: 56.

28. Demiroğlu M, Karakaş M. 5 dakikada 2012 Avrupa insan sermayesi etkinlik raporu. Pricewaterhouse Coopers. 2012.

29. Kayabalı K. İlaç sektörünün eğitimlerinin son 10 yılında trend değişimi 2011. http://www.ozanbatigun.com/ Erişim Tarihi: 25.09.2014.

30. Porter-O'Grady T, Malloch K. Quantum Leadership: A Resource for Health Care Innovation. Jones and Bartlett Publishers, USA. 2007.

31. McAlearney AS. Leadership development in healthcare: A qualitative study. J Organ Behav 2006;27: 21-32.

32. Yiğit R. Klinik sorumlu hemşirelerinin liderlik davranışları. C Ü Hemşirelik Yüksekokulu Dergisi 2000;4:21-32.

33. Tengilimoğlu D, Yiğit A. Hastanelerde liderlik davranışlarının personel iş doyumuna etkisini belirlemeye yönelik bir alan çalışması. Hacettepe Sağlık İdaresi Dergisi 2005;8:374-400.

34. Erkan E, Aban S. Devlete ve özel sektöre bağlı hastanelerde çalışan servis sorumlu hemşirelerinin işe ve insana yönelik liderlik yönelimlerinin incelenmesi. Hemşirelik Yüksekokulu Dergisi 2006;1-13.

35. Karahan A. Hastanelerde liderlik ve örgütsel bağl1lık arasındaki ilişkinin incelenmesi. Sosyal Bilimler Dergisi 2008;10:145-62.

36. Ateş H, Çetinkaya NI, Es M. Değişim çağında hastane yöneticilerinin vizyoner liderlik profilleri. 2. Uluslararası Sağlıkta Performans ve Kalite Kongresi. Ankara: Sağlık Bakanlığı Tedavi Hizmetleri Genel Müdürlüğü Yayınları, 2010.

37. Özkurt E, Işık U, Elitez B, Işsk İ. Sağlık hizmetlerinde vizyoner liderlik: Eskişehir ilinde bir uygulama. 2. Uluslararası Sağlıkta Performans ve Kalite Kongresi. Ankara: Sağlık Bakanlığı Tedavi Hizmetleri Genel Müdürlüğü, 2010.

38. Aslan Ş, Özata M. Sağlık Çalışanlarında Hizmetkar Liderlik: Dennis-Winston ve Dennis-Bocernea Hizmetkar Liderlik Ölçeklerinin Geçerlik ve Güvenirlik Araştırması. Yönetim ve Ekonomi. 2011;18:139-54.

39. Yeşilkayalı F, Kılıç B. İzmir ili kamu sağlığı yöneticilerinin liderlik davranışları. 15. Ulusal Halk Sağlığı Kongresi. Bursa, 2012. 
40. Göksel A, Aydıntan B. Lider-Üye Etkileşimi Düzeyinin Örgütsel Bağlılık Üzerine Etkisi: Görgül Bir Araştırma. Süleyman Demirel Üniversitesi İktisadi ve İdari Bilimler Fakültesi Dergisi 2012;17:247-71.

41. Aksoy S. Etik Liderin ve Etik İklimin İş Performansına Etkisi: İlaç Mümessilleri Üzerinde Yapılan Bir Araştırma. 18. Ulusal Pazarlama Kongresi. Kafkas Üniversitesi İktisadi ve İdari Bilimler Fakültesi Sarıkamış, 2013.

42. Öztürk H, Kahriman İ. The opinions of nurse students regarding leadership in nursing. Procedia Soc Behav Sci 2013;93:111-5.

43. Özcömert GH, Özçelikay G, Şar S, Asil E. Yararlılık ve zarar vermeme ilkelerinin eczacılık etiği açısından değerlendirilmesi. T Klin J Med Ethics 2000;8:101-4.

44. Sánchez-Serrano I. Chapter 10: Causes of the Pharmaceutical Crisis. In: The World's Health Care Crisis. Elsevier, London. 2011.

45. Busfield J. 'A pill for every ill': Explaining the expansion in medicine use. Soc Sci Med 2010;70:934-41.

46. Abacıŏlu N. Türkiye İlaç Sanayi. İstanbul Ticaret Odası Yayınları, İstanbul. 2010. Yurtiçi Sektörel Etütler ve Araştırmalar Yayın No: 2009-41.

47. Turan N. Kuruluşundan Günümüze Türkiye İlaç Endüstrisi. Skala Yayıncılık, İstanbul. 2007.

48. Baytop T. Türk Eczacılık Tarihi. İstanbul Üniv.Yay.No.3358 Eczacil1k Fak.No.78, İstanbul. 2001.

49. T.C. Bilim, Sanayi ve Teknoloji Bakanlığı Sanayi Genel Müdürlüğü. İlaç Sektörü Raporu. Ankara: T.C. Bilim, Sanayi ve Teknoloji Bakanlığı Sanayi Genel Müdürlüğü Sektörel Raporlar ve Analizler Serisi; 2013.

50. Sayar F. Türkiye İlaç Sektörü Stratejisi Ön Hazırlık Toplantısı. Ankara: T.C. Bilim, Sanayi ve Teknoloji Bakanlığı Sanayi Genel Müdürlüğü; 2012.

51. T.C. Ekonomi Bakanlığı İhracat Genel Müdürlüğü Kimya Ürünleri ve Özel İhracat Daire Başkanlığı. İlaç ve Eczacılık Ürünleri Sektörü. Ankara: T.C. Ekonomi Bakanlığı; 2010.

52. Türkiye Odalar ve Borsalar Birliği İlaç Sanayi Meclisi. Türkiye İlaç Sanayi Meclisi Sektör Raporu. Ankara: Türkiye Odalar ve Borsalar Birliği; 2012.

53. Miller R. Key transitions in the pharmaceutical industry: Technical leader to group leader. The Faculty of Pharmaceutical Medicine of the Colleges of Physicians of the United Kingdom Faculty Newsletter 2012.

54. Tarcan Aksal A. 7 Ortak Özellik. http://www.capital.com.tr/ insan- kaynaklari/7-ortak-ozellik-haberdetay-4997 Erișim Tarihi: 01.04.2008.

55. Knutsen LJS. Drug discovery management, small is still beautiful: Why a number of companies get it wrong. Drug Discov Today 2011;16: 476-84.

56. Leslie JB, Palmisano K. The leadership challenge in the pharmaceutical sector: What critical capabilities are missing when it comes to leadeship talent and how can they be developed? Center for Creative Leadership, 2010.

57. Sundgren M, Styhre A. Leadership as de-paradoxification: leading new drug development work at three pharmaceutical companies. Leadership-London 2006;2:31-52.

58. Deeds DL, DeCarolis D, Coombs J. Dynamic capabilities and new product development in high technology ventures: An empirical analysis of new biotechnology firms. J Bus Venturing 2000;15:211-29.

59. Laínez JM, Schaefer E, Reklaitis GV. Challenges and opportunities in enterprise-wide optimization in the pharmaceutical industry. Comput Chem Eng 2012;47: 19-28.

60. Costa Font J, Sato A. Health systems futures: The challenges of technology, prevention and insurance. Futures 2012;44:696-703.

61. Wang CJ, Ellender SM, Textor T, Bauchner JH, Wu JY, Bauchner H, Huang AT.A proposed framework for understanding the forces behind legislation of universal health insurance: lessons from ten countries. Health Serv ResN 2011;46: 2101-18.

62. Bilgener E, Asil E, Özçelikay G. The role of promotion on marketing in Turkish drug industry. Turk J Pharm Sci 2004;1: 87-104.

63. Sawyer TK. Transformational leadership in drug discovery by way of virtuous thought, word and deed. Chem Biol Drug Des 2008;71: 507-8.

64. Örnek Büken N, Yeğenoğlu S. Physician-industry relationships and promotion ethics in Turkey. Clin Res Regul Aff 2003;20: 379-89.

65. Strom BL. Risk assessment of drugs, biologics and therapeutic devices: present and future issues. Pharmacoepidemiol Drug Saf 2003;12: 653-62.

66. Upton J. Turkey: A Promise Restored: Pharmaceutical Executive; ttp://www.pharmexec.com/pharmexec/Global/ Turkey-A-Promise- Restored/ArticleStandard/Article/ detail/805003 Erişim Tarihi: 21.03.2013.

67. Buharalı C. Türkiye'de sağlık ekonomisi ve ilaç sanayi. Deloitte Türkiye. 2011. 